\title{
'I have a real sense of fulfilment achieving a straightforward caseload completed well'
}

\section{Interview by Kate Quinlan}

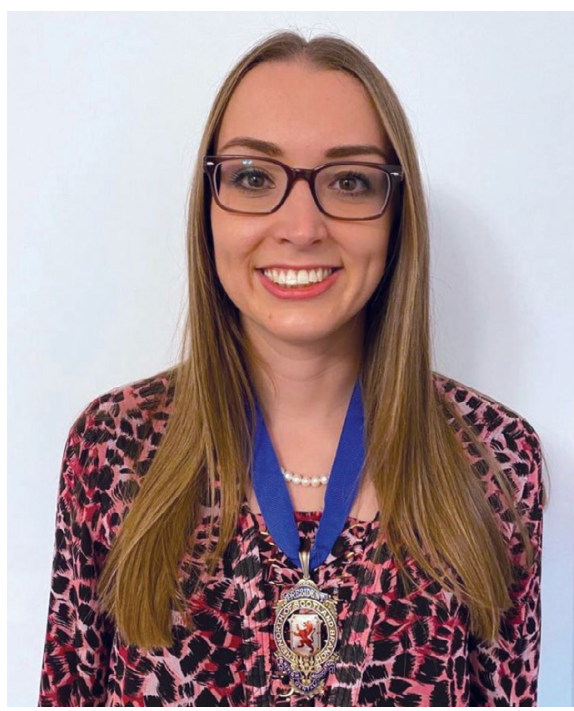

Where are you from?

I was brought up in the small coastal village of St Fergus, 40 miles north of Aberdeen in the North East of Scotland. I attended Peterhead Academy prior to studying dentistry at the University of Dundee. On completion of my dentistry studies in 2015, I returned to Aberdeen where I am still based.

\section{What attracted you to dentistry?}

From a very young age, I enjoyed going to the dentist - I suspect because my dentist gave me lots of time. I specifically remember when he raised and lowered the dentist's chair! The fun I enjoyed then has always stayed with me and so I aim to do the same, thereby gaining as much co-operation as possible from small children.

Mum and I had 'family' dental appointments. First the dentist saw me and then I would stand next to the bracket table to watch closely all the dentist did during mum's turn. I also really liked the drawer with the interdental brushes, polishing burs, wedges, matrix strips and so forth - not knowing what anything was, but attracted by all their colourful variety. My dentist visit was always rounded off with an invitation to choose a sticker - always a difficult choice!

\author{
Carly Fraser is the 2021 recipient of the British Dental Association's (BDA's) \\ Joy Harrild Award for Young Dentists. Carly, who is a GDP at Banff Dental \\ Practice on the Moray Firth coast of Aberdeenshire, has been the North of \\ Scotland Representative within the BDA's Scottish Council since March 2018 \\ and according to the BDA, has shown 'exemplary initiative in organising \\ events and functions, going above and beyond to ensure they are a success'.
}

I remember my granny asking me then: 'what do you want to do when you grow up?' and I would unhesitatingly reply: 'a dentist'.

What did you think of your BDS course? I studied at the University of Dundee from 2010-2015. It was not plain sailing the whole way. During first and second year I was very homesick and was close to giving up and moving back home; I am grateful to my student advisor and my flatmate for counselling me to stay. Third year proved a turning point: starting practical learning on the phantom heads and treating real patients on clinic, I thoroughly enjoyed my final three years. I highly rate my BDS course; our degree programme was well structured and our lecturers combined expert knowledge and practice in teaching us dental theory and clinical skills.

\section{Can you outline your career history and places of work?}

My VT post was with Abercrombie Dental Practice, Westhill, Aberdeenshire in 2015/2016, then continuing there as an Associate until March 2017.

In March 2017, I took over a maternity cover position at Union Street Dental Care in the centre of Aberdeen City. Then, in December 2017 I started working for BUPA within their Peterhead and Mintlaw practices where I was registered as a patient. At graduation, I recall saying I never wanted to treat friends and acquaintances!

Two years later, an opportunity arose at Banff Dental Practice in the far North East of
Scotland, a challenging decision: a positive move for my personal and professional career development within dentistry but it involved a commute of over an hour each way. I took up the post in Banff and have now practised there for two and a half years.

\section{Which are your main areas of interest within dentistry?}

I have most interest and 'job satisfaction' in doing 'routine' dentistry to my best ability and to a high standard for my child and adult patients. I still vividly remember at university when we were doing our final year case presentations my supervisor said: 'often the best cases are simple cases done well. Those wise words have become my professional maxim. I have a real sense of fulfilment achieving a straightforward caseload completed well. What I appreciate and enjoy most is the variety that each day brings. Being a GDP in practice is where I feel I am meant to be, for the time being anyway.

\section{Do you plan to specialise in the future?} I have never had a desire to specialise and have no current plan to specialise; rather, I aim to continue to broaden my experience as a GDP in practice. In 2019, after discussion with my current principal, we decided I should apply to be a VT trainer. Having completed my VT just three years previously this seemed like a big career step. The COVID-19 era of 2020 was certainly a unique and challenging year to commence vocational training for both VT and trainer. 
4 How do you spend a typical week?

Outwith dentistry, I enjoy being active including being a competitive swimmer. A typical week will involve working in Banff on Monday to Thursday, leaving home at 7 am and returning around $6 \mathrm{pm}$. Generally, on one evening each week I will participate in a dental activity: either a webinar, CPD event or committee meeting. I swim with my club, 'Aberdeen Dolphins', on Monday, Thursday and Friday evenings with another session on a Sunday morning. My partner is a keen runner and introduced me to the sport. We generally attend together with the 'Fit Like Joggers' in Aberdeen on a Wednesday evening then run a ParkRun at nearby Crathes Castle estate on a Saturday morning. Swimming is something I have participated and competed in from nine years old, balancing the demands of attending training alongside either studying or working. Swimming offers me both exercise and relaxed time with friends outside of the working environment. My current swimming goals are to come close to - or break Scottish Masters records and to compete at the European Masters Championships in Rome in late summer 2022.

\section{How has the pandemic affected you workwise?}

COVID-19 has unfortunately hit dentistry hard. My clinical days in practice have been reduced and social distancing requirements as well as fallow and cleaning times limit the number of patients we can treat daily. The physical and psychological demands of working in full PPE and the negativity of (some) patients about our modified practices in response to the pandemic have taken a toll, definitely demanding ability to persevere in those adverse circumstances through personal and professional resilience. Fortunately, my practice nurse, Mel and partner, Ben are amazingly positive and excellent at supporting me both in and out of work.

Due to the requirements in general practice and not working in dentistry full time, I opted to take up a position within the COVID-19 Aberdeen Vaccination Clinic generally working one shift each week. This has been a positive experience, an opportunity to acquire, develop and practise new skills and to meet some great new colleagues, alongside people from different areas of healthcare.
The seemingly uncertain future of NHS dentistry gives me some cause for concern. It seems increasingly important to continue to work diligently within our BDA committees to try to achieve a good resolution.

\section{How did you spend your time during lockdowns?}

The pandemic news signalled that 'lockdown' was coming. Living alone at the time, I packed my car to go home to 'bubble' with my parents for the lockdown period. As it happened, I got very ill the weekend before we went into lockdown and over the course of that week. On my third visit to 'out of hours' NHS care in four days I was diagnosed with shingles of the right inferior dental alveolar nerve; I am uncertain whether COVID-19 was also a factor. I was unable to care for myself and so I spent the first six weeks or so at home with my parents. Most of this time was spent trying to recuperate, although also included making a birdhouse and painting large pebbles collected from the nearby beach as 2020 mementos.

On my return to health and to Aberdeen, I spent a lot of time doing BDA committee work, weekly LDC meetings and multiple weekly webinars. I always made the most of our 'daily hour of exercise' by going on walks or runs. By summer, I really missed swimming, so decided to try open water river swimming locally - only to very quickly appreciate I would never be a regular cold water swimmer!

Why do you think you were nominated for the Joy Harrild Award?

In the North East of Scotland it is difficult to fill committee positions or have the numbers needed to form a functioning committee. I believe I was nominated for the Joy Harrild Award in recognition of my care of patients, my support of colleagues, my contribution to the BDA and to our profession in volunteering to serve on four dental committees. Due to my colleagues' appreciation of the amount of work, dedicated time and consistent enthusiasm and resilience that committee work and its associated commitments and activities involves, this has led to where I am now.

\section{How did it feel to win?}

I was extremely surprised, elated and deeply honoured to have won such a prestigious national award from my colleagues and profession. I immediately remembered my very young self confidently informing my granny I was going to be a dentist... and thinking how happy and proud granny would have been that I had fulfilled my childhood dream. My two elder cousins and I are the first generation in our direct family to go to university and I was delighted for my parents and wider family that I had won such an accolade. This award not only recognises the work I have done, but also the immense amount of support, reassurance and shoulders to cry on that those around have provided me with: for this I could not be more appreciative.

\section{Any future plans you'd like to share, career} or otherwise?

My current career plan is to continue to remain happy, work, learn and to develop my skills within general practice, VT training and to carry on with my BDA committee work.

Would you encourage others to nominate a young dentist for the Joy Harrild award? One hundred percent yes! I had previously read the award nomination criteria and while I recognised that I 'ticked a lot of the boxes' I never thought I would deserve to be nominated, given there are so many successful young dentists who have chosen to specialise and have amazing goals and aspirations. It just goes to show that if you work hard, try your best in dentistry, including doing the 'simple' aspects of practice to the highest standards (in the wise words of my university supervisor), good things will come. If you meet the award criteria go ahead and get someone to nominate you; and if your experience and professional contribution does not (yet) fulfill the award criteria, then identify what you need to do: work hard to overtake all the criteria and make yourself deserving of the Joy Harrild Award!

The BDA's Joy Harrild Award for Young Dentists is open for nominations for dentists who are within ten years of qualifying who have made a significant contribution to the profession. Nominations for the next round close on 29 April 2022. For more information and to nominate, visit https://www.bda. org/about-the-bda/honours-and-awards/ joy-harrild-award-for-young-dentists. 